\title{
CARBON CREDITS COMPETE POORLY WITH AGRICULTURAL COMMODITIES IN AN OPTIMIZED MODEL OF LAND USE IN NORTHERN CALIFORNIA ${ }^{\star}$
}

\author{
ERIK NELSON ${ }^{*}, \dagger \S$ and VIRGINIA MATZEK \\ *Department of Economics, Bowdoin College, Maine, USA \\ ${ }^{\dagger}$ Centre for Environmental and Climate Research \\ Ecology Building, Lund University, S-223 62 Lund, Sweden \\ Department of Environmental Studies and Sciences \\ Santa Clara University, California, USA \\ §enelson2@bowdoin.edu
}

Accepted 30 June 2016

Published 26 August 2016

\begin{abstract}
Nascent US carbon markets reward farmers for reforesting agricultural land, with consequent ecological co-benefits. We use a dynamic optimization model to determine the likelihood of an orchard farmer in northern California converting to forest under 90 plausible future scenarios. We find reforestation to be a highly unlikely outcome, occurring only $4.0 \%$ of the time under current economic, biophysical, and policy conditions, and only $18.5 \%$ of the time under a set of assumptions that make carbon offset production more economically viable. Conversion to "carbon farming" was more sensitive to changes in orchard production costs and yields than to carbon offset policy changes. In the absence of other changes, the price of a carbon offset would have to increase nearly a hundredfold to make reforestation compete economically with orchard agriculture. Our results partly explain low participation in the reforestation sector of US carbon markets. We conclude that farmers will not be interested in forest conversion unless their land has limited agricultural potential or they are motivated by social, rather than economic, rewards.
\end{abstract}

Keywords: Carbon credits; reforestation; orchards; dynamic optimization; AB32; CARB.

\section{Introduction}

Reforesting land that was cleared for agriculture or other economic exploitation holds promise for climate mitigation (Canadell and Raupach, 2008), with potential cobenefits for biodiversity and other ecosystem service provision (e.g., Gilroy et al., 2014). Globally, the total potential sequestration from reforestation has been estimated

\footnotetext{
This is an Open Access article published by World Scientific Publishing Company. It is distributed under the terms of the Creative Commons Attribution 4.0 (CC-BY) License. Further distribution of this work is permitted, provided the original work is properly cited.

* This article contains supplementary material available on the journal website. The supplementary material includes details on orchard economics, crop price modelling, perpetual easement economics (including the generation of carbon credits), and implementation of the dynamic optimization model in MATLAB.
} 
at up to $1.5 \mathrm{Pg} \mathrm{C}$ year $^{-1}$ over the next century, but only a fraction of this sequestration is likely to occur, due to the opportunity cost of reforesting arable and other productive lands (Canadell and Raupach, 2008; Strengers et al., 2008; Canadell and Schulze, 2014).

Regulators in many countries have established compensation schemes to make reforesting more lucrative. In the US, landowners who increase forest cover on their lands can earn marketable carbon credits through two regional cap-and-trade mechanisms, the California Air Resources Board (CARB) program and the Regional Greenhouse Gas Initiative of the Mid-Atlantic and Northeast states (ReGGIe). While it is widely recognized that these mechanisms will impact carbon and energy markets in the US, these programs also have the potential to impact land use patterns, rural livelihoods, wildlife habitat, and ecosystem service provision across the country.

Research on the impact that regional carbon cap and trade programs like CARB and ReGGIe could have on land use and management at the US farm-level is sparse. Previous work on reforestation on US farms in exchange for a carbon credit or payment has typically been conducted at the landscape level with fairly crude opportunity cost of carbon farming models (Parks and Hardie, 1995; Lubowski et al., 2006). In these models, the marginal cost of supplying carbon is based on highly aggregated net return data; cost heterogeneity within a region is solely driven by soil and climate gradients. Further, these models are static and do not account for the extended periods of forest cover required under the carbon programs. Finally, given their broad spatial scope, these models are not designed to determine the impact of changes in carbon policy or farming costs on decision making at the farm level.

There are some models of farm-level participation in other kinds of conservation programs. For example, recent work modeled a US farmer's willingness to sequester additional soil carbon via conservation tillage and other land-management options in exchange for a payment (Antle et al., 2003). Decisions surrounding participation in the US Conservation Reserve Program (CRP) have also been the subject of farm-level modeling (Isik and Yang, 2004). While the CRP does not focus on carbon sequestration, it has some similarities to a "carbon farming" program, as participation requires taking farmland out of production and planting it in a perennial species, typically prairie grasses or riparian shrubs and trees. However, these aforementioned farm-level models do not apply well to decision making spurred by the new cap-andtrade programs, for several reasons. In the soil carbon model, the farmer can still grow crops while accruing carbon credits (an impossible choice in reforestation programs). Furthermore, in both farm-level models, a conservation choice can be reversed relatively quickly. For example, CRP contracts typically last for 15 years.

In this study, we combine carbon sequestration field data with detailed information on realistic costs and returns from agricultural activities to determine the likelihood that a hypothetical farmer in our study area will convert land to perpetual forest in exchange for carbon credits that could be sold in the CARB, ReGGIe, or similar programs. We use a dynamic optimization model in which the farmer chooses land uses over time to maximize the present value of net returns. We introduce plausible 
future changes into the model - such as increased yields, higher commodity prices, water scarcity, a rise in the value of carbon credits, regulatory changes, etc. - to determine which changes have the greatest impact on optimal land use trajectories, particularly optimal land use trajectories that include carbon farming. We also use the model to determine the hypothetical farmer's forest supply curve under default scenario assumptions.

Our hypothetical farmer is a landowner in the fruit- and nut-growing region of the Central Valley of California. We chose this agricultural system as a model because several of its features seem particularly favorable to land use conversion from agriculture to forest carbon farming. First, orchard growers, unlike annual commodity farmers, already have the appropriate equipment and expertise for silviculture and are accustomed to waiting up to a decade for net returns from tree-planting to become positive. Second, climate change is threatening orchard culture in the Central Valley by disrupting the water supply patterns that these farms rely on (Hayhoe et al., 2004; Swain et al., 2014; Diffenbaugh et al., 2015) and decreasing the chilling hours needed for fruit to develop (Baldocchi and Wong, 2008). Third, Central Valley growers are likely to be familiar with reforestation techniques and outcomes, because more than 6,000 acres of native forest have been restored on abandoned agricultural lands in the region since 1989, and such parcels often sit adjacent to orchards that are still in production (Golet et al., 2013). Fourth, detailed information on carbon accumulation in Central Valley forest types (Matzek et al., 2015) and the economics of agriculture (Duncan et al., 2011; Buchner et al., 2012; Krueger et al., 2012; Grant et al., 2013; Lile et al., 2013; Wright et al., 2013) exist for this system, making it easier for a farmer to estimate and compare returns from carbon credits and current agricultural activities.

In our model, possible land uses include planting a forest for carbon credits, haying, or growing almonds, walnuts, or prunes. We treat converting to forest as an irreversible choice (we do not consider the case where the farmer repays the forest easement payment and carbon credits after abandoning a forest), but otherwise the farmer can switch from one land use to another. We find optimal land use trajectories under 90 different scenarios that vary future cost, price, and regulatory requirement assumptions. For each scenario we solve the model 1,000 times where each run assumes a unique commodity price trajectory and farmers can perfectly forecast prices. We calculate the likelihood of forest conversion under a scenario as the percentage of the 1,000 scenario runs in which carbon farming is adopted at any point. Finally, we calculate the farmer's forest supply curve under the default scenario.

We find that conversion of agricultural land to forest for the purpose of earning carbon credits is a highly unlikely outcome, occurring only $18.5 \%$ of the time even under the scenario with a set of assumptions that greatly increase the net returns to forestry and significantly reduce the net returns to orchard use. The likelihood of transitioning to carbon farming was relatively insensitive to policy changes, and depended most on changes to orchard production costs and yields. 


\section{Methods}

\subsection{Annual net returns on the farm}

Assume a farmer of 100 acres whose goal is to maximize the present value of net returns to her land over infinite time. (Orchards in this area of California typically cover 100 acres; see Duncan et al., 2011; Buchner et al., 2012; Grant et al., 2013.) Over the course of time, indexed by $t$, the farm is always in one of the following land uses $j$,

- Almonds (40 acres) and wheat (60) acres $(j=1)$;

- Walnuts (60 acres) and wheat $(40)$ acres $(j=2)$;

- Prunes (100 acres) $(j=3)$;

- Pasture (100 acres) $(j=4)$; or

- Perpetual forest with a conservation easement (100 acres) $(j=5)$,

where $x_{j t}=1$ indicates that the farm is in use $j$ at time $t$ and $x_{-j t}=0$ for all other land uses $-j$. For example, if the farm is in almonds in year $t$ then $x_{1 t}=1$ and $x_{2 t}=x_{3 t}=x_{4 t}=x_{5 t}=0$. Net return to land use type $j$ in year $t$ is,

$$
n r_{t}\left(x_{j t}\right)=a_{j}\left[p_{j t} y_{j t(s)}-c_{j t(s)}\right]+\left(100-a_{j}\right)\left[p_{z t} y_{z t}-c_{z t}\right]+m_{j t(s)}-k_{j t},
$$

where $a_{j}$ is the area of $j$ in acres, $p_{j t}$ is the real per unit market price for the commodity (not including wheat) produced by land use $j$ in time $t, y_{j t(s)}$ is per-acre yield of $j$ 's commodity in year $t$ given $j$ is in year $s$ of a rotation, $c_{j t(s)}$ is $j$ 's real per-acre operating cost in year $t$ given $j$ is in year $s$ of a rotation, $m_{j t(s)}$ is any other net payment that accrues to $j$ in year $t$ given it is in year $s$ of its rotation, and $k_{t}$ is the sum of all amortized sunk capital costs the farmer has to pay in year $t$. In two cases, $j=$ almonds and walnuts, $100-a_{j}>0$ and the farm will generate an annual net return from wheat production as well where $p_{z t}, y_{z t}$, and $c_{z t}$ are the per-unit price, per-acre yield, and peracre annual cost of wheat production, respectively, in year $t$. For all other land uses $a_{j}=100$. The commodity produced by a pasture is hay and the commodity produced by a forest is a carbon credit. The number of credits yielded by a forest is detailed in CARB (2013) and this article's Supplementary Material. All costs, operating and capital, are current as of circa 2011 and either come from the University of California Cooperative Extension budget sheets for almond, walnut, prune, wheat, and hay production in the Central Valley of California (Duncan et al., 2011; Buchner et al., 2012; Krueger et al., 2012; Grant et al., 2013; Lile et al., 2013; Wright et al., 2013) or estimates of the costs associated with a qualifying forest offset project in California (Saah et al., 2012; CARB, 2013). Given the timing of the cost data we can consider 2011 as year $t=0$. Because a forest that earns credits has to be maintained for perpetuity, the forest will never generate timber value (we do not consider the case where a landowner removes a forest and is penalized for such behavior).

Equation (1) does not account for all components of land value; it is not intended to find land values. Instead it compares net return streams from five alternative uses, 
ignoring those land value components that are common across all uses, or irrelevant to decide which use returns the greatest net present value.

To make our simulation of Eq. (1) over infinite time more tractable we stop tracking land use choices and $n r_{t}\left(x_{j t}=1\right)$ after 100 years. This arbitrary truncation does not materially affect our analysis for several reasons. First, given an assumed per annum discount rate of $7 \%, \sum_{t=0}^{99} \frac{n r_{t}\left(x_{j t}=1\right)}{(1+\delta)^{t}} \approx \sum_{t=0}^{\infty} \frac{n r_{t}\left(x_{j t}=1\right)}{(1+\delta)^{t}}$ no matter what land use choices are made after $t=100$. To demonstrate the relative unimportance of net returns after 100 years consider the following scenario: if $n r_{t}\left(x_{j t}=1\right)=1,000$ each year until $t=100$ and doubles to $\$ 2,000$ per year for the rest of time then $\sum_{t=0}^{99} \frac{n r_{t}\left(x_{j i}=1\right)}{1.07^{t}}=\$ 15,268$ and $\sum_{t=0}^{\infty} \frac{n r_{t}\left(x_{i t}=1\right)}{1.07^{t}}=\$ 15,302$ for a difference of $\$ 34$. In other words, the land use trajectory that maximizes $\sum_{t=0}^{99} \frac{n r_{t}\left(x_{j}=1\right)}{1.07^{t}}$ will almost always form the first 100 years of the land use trajectory that maximizes $\sum_{t=0}^{\infty} \frac{n r_{t}\left(x_{j i}=1\right)}{1.07^{t}}$. Second, even though our simulations cannot answer how often orchards will adopt forestry projects more than 100 years from now, that is not problematic from a policy analysis point of view, as the purpose of carbon credit programs is to provide immediate carbon sequestration, not carbon sequestration centuries hence.

We generate the price matrix $\left[p_{1 t}, p_{2 t}, p_{3 t}, p_{4 t}, p_{z t}\right]_{t=0}^{99}$ with a random walk where $\left[p_{1,0}, p_{2,0}, p_{3,0}, p_{4,0}, p_{z, 0}\right]$ is given by the average of observed 2001 to 2012 California prices in 2011 dollars (NASS, 2015). We construct the annual price covariance-variance matrix used in the random walk by fitting a multivariate normal distribution to observed real 2001 to 2012 almond, walnut, prune, hay, and wheat prices (see the article's Supplementary Material). Finally, the initial price of a carbon credit is given by $p_{5,0}$ and the price at time $t$ is given by $p_{5 t}=p_{5,0}(1+r)^{t}$ where $r$ is the assumed annual rate of credit value increase.

We use a random walk to model commodity price evolution for several reasons. First, given that we want to simulate landowner decisions over a rich set of price trajectories and policies, the creation of more extreme price trajectories is desirable. A random walk produces some extreme price trajectories as price shocks do not dissipate over time (for the random walk the mean is stationary but its variance is not). Second, evidence is emerging that commodity price variance has increased in climate change (McCarl et al., 2008; Abbott et al., 2011; Difenbaugh et al., 2012). Therefore, a commodity simulation model that uses a random walk to model future commodity prices is more appropriate than a process where variance is stationary.

Operating costs for use $j$ vary by rotation year of the land use. In rotation year $s=1$ operating cost $c_{j t(s)}$ includes land preparation and crop or tree establishment costs. Harvest costs are included in $c_{j t(s)}$ as of $s=2$ on pasture and several $s$ later on orchards. The term $c_{j t(s)}$ can also include the costs of irrigation water, chemical use (e.g., fertilizers, pesticides, etc.), labor, fuel use, tree pruning, honeybee rental, and rodent traps for orchard and pasture uses. Orchard and pasture use has a terminal rotation year. In the terminal rotation year $s$ operating cost term $c_{j t(s)}$ includes the cost 
of removing grasses or trees in preparation for a new rotation of the current cover or a new land use $j$. Cash overhead costs common to all land uses, such as property taxes, office expenses, liability insurance, sanitation fees, etc., are not included in $c_{j t(s)}$ for any $j$. The operating cost for wheat, $c_{z t}$, is not a function of $s$ because wheat is an annual crop. Finally, for a given $j, c_{j t^{\prime}(\bar{s})}$ does not have to equal $c_{j t(\bar{s})}$ when $t^{\prime} \neq t$ despite the common rotation age $\bar{s}$. For example, the price of nitrogen fertilizers has fallen over time and is expected to fall even farther in the future. See this article's Supplementary Material for details on $c_{j t(s)}$ for all $j$ and $s$ across all years $t$.

In year $t$ the farm is responsible for a total sunk capital cost of $k_{j t}$. The term includes amortized capital costs unique to the farm's land use $j$ in year $t$ and any outstanding amortized capital costs from previous land uses that have not yet been paid in full. To be consistent with the operating cost component of Eq. (1), this total capital cost does not include the cost of capital that is common to all land uses. ${ }^{1}$ To exemplify how $k_{j t}$ is calculated consider the following scenario. Suppose in year $t=0$ the famer establishes a prune orchard $\left(x_{3,0}=1\right)$. Capital equipment unique to a prune orchard includes a $\$ 43,50075$ horsepower, 4-wheel drive tractor, a $\$ 150,000$ irrigation well and pump system, and a $\$ 140,000$ drip irrigation apparatus. The tractor has a salvage value of $\$ 8,469$ at the end of its 15 -year use span. The well and irrigation apparatus have no salvage value at the end of their 30-year use spans. Therefore, at time $t=0$ the farmer commits to a loan equal to $\$ 337,728$ where loan payments are amortized over 30 years at an annual interest rate of $4.75 \%$ (a prune rotation is 30 years). ${ }^{2}$ This annual cost is sunk for the next 30 years even if, for example, the farmer transitions to almond land use at time $t=14\left(x_{1,14}=1\right)$. In this case, $k_{1 t}$ for $t=14$ to $t=29$ would include the annual prune sunk cost and the annual loan payment necessary for the capital unique to an almond orchard. Then, assuming the land remains in almonds for one rotation of 25 years, $k_{1 t}$ for $t=30$ to $t=39$ would only include the annual sunk cost unique to almond farming. As we did with operating $\operatorname{cost} c_{j t(s)}$, we leave open the possibility that $k_{j t}$ can change over time due to technological progress and market forces.

In our case, the net payment $m_{j t(s)}$ term is only relevant in the first year of forest cover $\left(x_{5 t}=1\right.$ where $\left.s=1\right)$. In a forest's first year, $s=1, m_{5 t(1)}$ is the sum of a onetime payment for the conservation easement that is attached to the farm's deed and the salvage value from the farmer selling two fuel tanks and a tractor that are only required by an intensively managed farm.

\footnotetext{
${ }^{1}$ We can drop these costs because we are interested in finding the land use trajectory that maximizes the present value of net returns to the farm and not necessarily the exact net returns to her land. See Supplementary Material for the list of capital equipment that is common to all five land uses and is therefore ignored in this analysis.

${ }^{2}$ This total value is given by $(\$ 43,500-\$ 8,469)+(\$ 43,500-\$ 8,469) / 1.07^{15}+\$ 150,000+\$ 140,000=\$ 337,728$. The term $(\$ 43,500-\$ 8,469) / 1.07^{15}$ is the present value of the second additional tractor that will need to be bought during a prune rotation. Recall the additional tractor only has a 15 year lifespan. Technically this second tractor would not have to be bought in our example given that the farmer abandons the prune orchard after 15 years. But for simplicity we include it as part of the annual sunk cost to prunes no matter when the prune orchard is abandoned. $4.75 \%$ is the annual loan interest rate assumed by the budget sheet used for this analysis.
} 


\subsection{Solving the problem}

The farmer chooses $x_{j t}=1$ for each time period $t=0, \ldots, 99$ such that the set of choices maximizes the net present value of the stream of annual net returns to her farm,

$$
\max _{x_{j 0}, x_{j 1}, \ldots, x_{j 100}} N R=\sum_{t=0}^{99} n r_{t}\left(x_{j t}\right) /(1+\delta)^{t} .
$$

Subject to:

$$
\begin{aligned}
x_{1 t}= & \{0,1\} \text { for } t=0-4,5-9, \ldots, 94-99, \\
x_{2 t}= & \{0,1\} \text { for } t=0-4,5-9, \ldots, 94-99, \\
x_{3 t}= & \{0,1\} \text { for } t=0-4,5-9, \ldots, 94-99, \\
x_{4 t}= & \{0,1\} \text { for } t=0-4,5-9, \ldots, 94-99, \\
x_{5 t}= & \{0,1\} \text { for } t=0-4,5-9, \ldots, 94-99, \\
& x_{1 t}+x_{2 t}+x_{3 t}+x_{4 t}+x_{5 t}=1 \forall t, \\
x_{5 t^{\prime}}= & 1 \forall t^{\prime}>t \text { if } x_{5 t}=1,
\end{aligned}
$$

where $\delta=0.07$ is the annual discount rate. For the sake of model tractability we assume that the representative farmer will only consider changing her land every five years. Therefore, the farm will be in its initial land use for the years $t=0-4$. At year $t=5$ the farm can be in a new use or in its previous use. This second decision lasts through year $t=9$ and then a land use decision has to be made for the years $t=10$ through 14 , etc. Further, we assume that forest land use is irreversible, but all other land use decisions are reversible. To solve (2) for a given price matrix $\left[p_{1 t}, p_{2 t}, p_{3 t}, p_{4 t}, p_{z t}\right]_{t=0}^{99}$ and defined $p_{5 t}$, $c_{j t(s)}$, and $k_{j t}$ for all $j, t$, and $s$ (i.e., one iteration of a scenario), we evaluate $1,725,961$ possible 100-year land use trajectories on the farm and retain the trajectory that returns the highest NR. See the article's Supplementary Material for details on how we built the set of land use trajectories and the MATLAB code that solves (2).

The major sources of uncertainty in problem (2) are: (1) the price matrix $\left[p_{1 t}, p_{2 t}, p_{3 t}, p_{4 t}, p_{z t}\right]_{t=0}^{99} ;$ (2) changes in orchard and forest use operation costs over time; (3) changes in orchard yields over time; (4) changes in $p_{5 t}$ over time; and (5) changes in carbon offset policies. To explore the consequences of uncertainty in problem (2) we have done the following:

First, we construct scenario $i$ where $p_{5 t}, c_{j t(s)}$, and annual capital costs are defined for all $j, t$, and $s$.

Second, we solve problem (2) for scenario $i 1000$ times where each iteration of the problem has a unique price matrix.

Finally, for every 1000 solutions to problem (2) under scenario $i$, we record the number of times a forest is placed on the farm at some point in the first 25 years $(t \leq 25)$, at some point in the first 50 years $(t \leq 50)$, and ever $(t \leq 99)$. We can use these results to understand how sensitive the choice to adopt carbon farming is to the uncertainty in key variables such as the price of carbon, the rules that govern forest projects, and the cost of irrigation water. 
Finally, while we contended earlier that truncating our simulation of an infinite process at 100 years does not materially affect the number of times that the solution (2) involves forestry use, it is likely that the truncation does make a solution to (2) that involves prune use, especially near $t=100$, slightly less likely. A farm that stays in almonds and orchards the whole 100 years will have completed its fourth rotation at the end of 100 years and the next five years of returns in such orchards (years 101-105) would be a period of negative returns. However, a continuous prune farm would still be in the middle of its fourth rotation at $t=100$ and just entering its prime annual net return period. Therefore, if we did run our simulation model another 50,100 , or 200 years we would be likely to find a few more optimal land use trajectories that included prune orchards in lieu of almonds or walnuts. However, our ultimate research aim is to estimate the likelihood that forest land use will occur at some point over the next 100 years, not whether almonds are more profitable than prunes. We are confident that the truncation has little to no effect on the number of times we find a land use trajectory that includes forest use in the farm's next 100 years.

\subsection{Scenarios}

We consider 90 scenarios. Scenario $i=1$ is the default scenario. Every other scenario $i$ involves at least one deviation from the default scenario. Here we briefly explain these deviations. (See Table 1 for a brief description of all scenarios other than the default and the article's Supplementary Material for many more details.) First, we describe the various changes to forest land use and carbon credit policy inputs to the model (socalled forest land use scenarios).

The default market value of a carbon credit earned by the farmer across all $t$ is $\$ 41.58$ (i.e., $p_{5 t}=\$ 41.58$ across all $t$ ) (Matzek et al., 2015). This is based on the April 2014 California auction reserve price of $\$ 11.34$ for a metric ton of $\mathrm{CO}_{2} e(\$ 41.58 \mathrm{in} \mathrm{Mg}$ of C). We alternatively consider $p_{5 t}=\$ 80$ across all $t$ or $p_{5 t}=\$ 80(1.01)^{t}$ for each $t$. These changes assume credits are more valuable than currently priced or, alternatively, are more valuable than currently priced and will continue to become more valuable over time.

The default value of the one-time easement payment that comes with forest establishment is $50 \%$ of the land's assessed value (Lassner, 1998). Land suitable for orchard cultivation in the Sacramento River valley has been assessed at $\$ 1,153$ acre $^{-1}$ (Krueger et al., 2012). Therefore, the default easement value is $\$ 1,153 \mathrm{acre}^{-1} \times 0.5=$ $\$ 577$ acre $^{-1}$ (i.e., $m_{5 t(1)}=577$ across all $t$ ). We alternatively consider an easement value of $\$ 1,000$ acre $^{-1}$ across all $t$.

The easement payment is offset by the one-time cost of establishing the forest. The default tree establishment cost is $\$ 891.41$ acre $^{-1}$ at any $t$ (Nielsen et al., 2014). ${ }^{3}$ This number is based on the observed cost of tree establishment in Conservation Reserve

${ }^{3}$ Nielsen et al. (2014) report a tree establishment cost in Sacramento County of $\$ 632.9$ acre ${ }^{-1}$ in $1997 \$$. This is $\$ 891.41$ acre $^{-1}$ in $2011 \$$. 


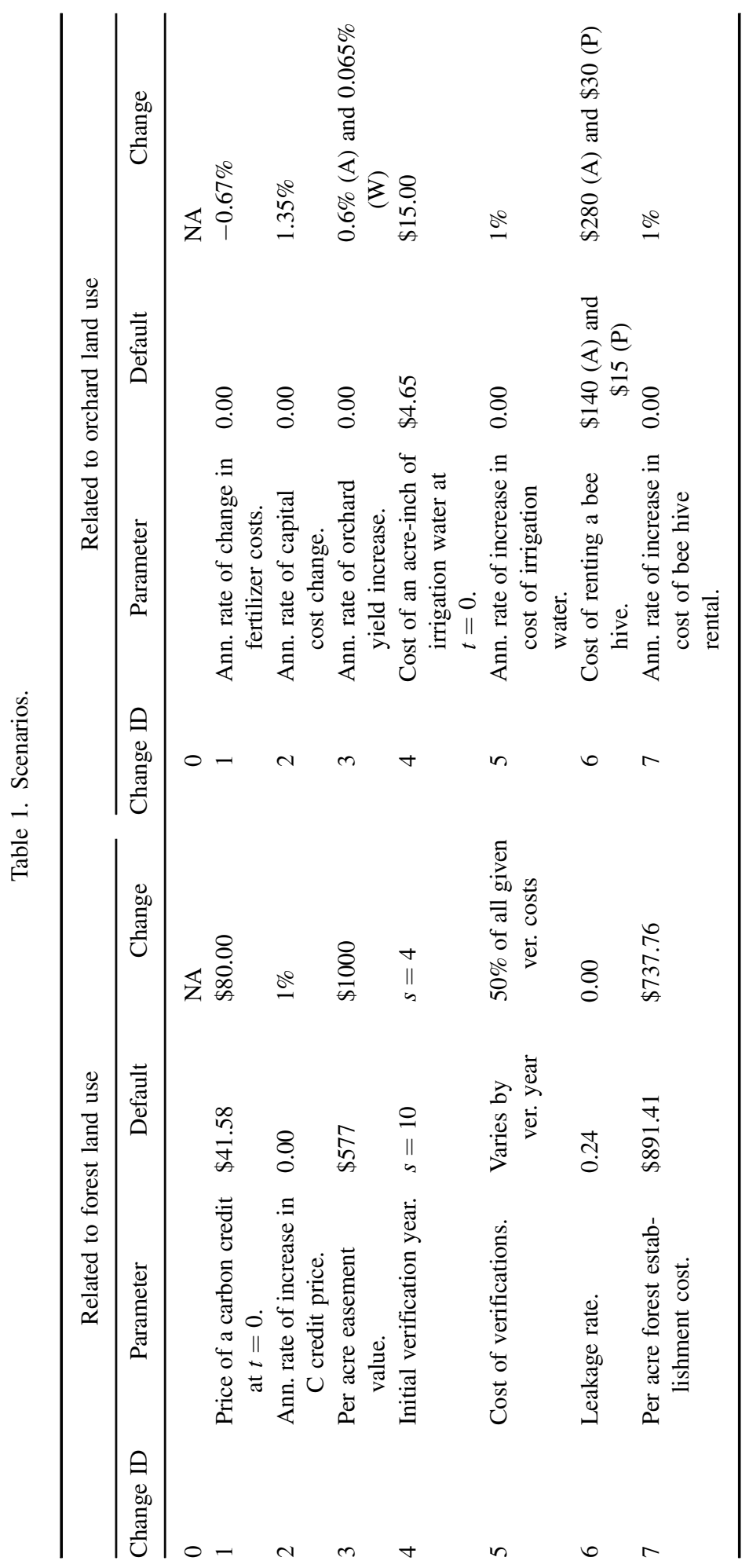




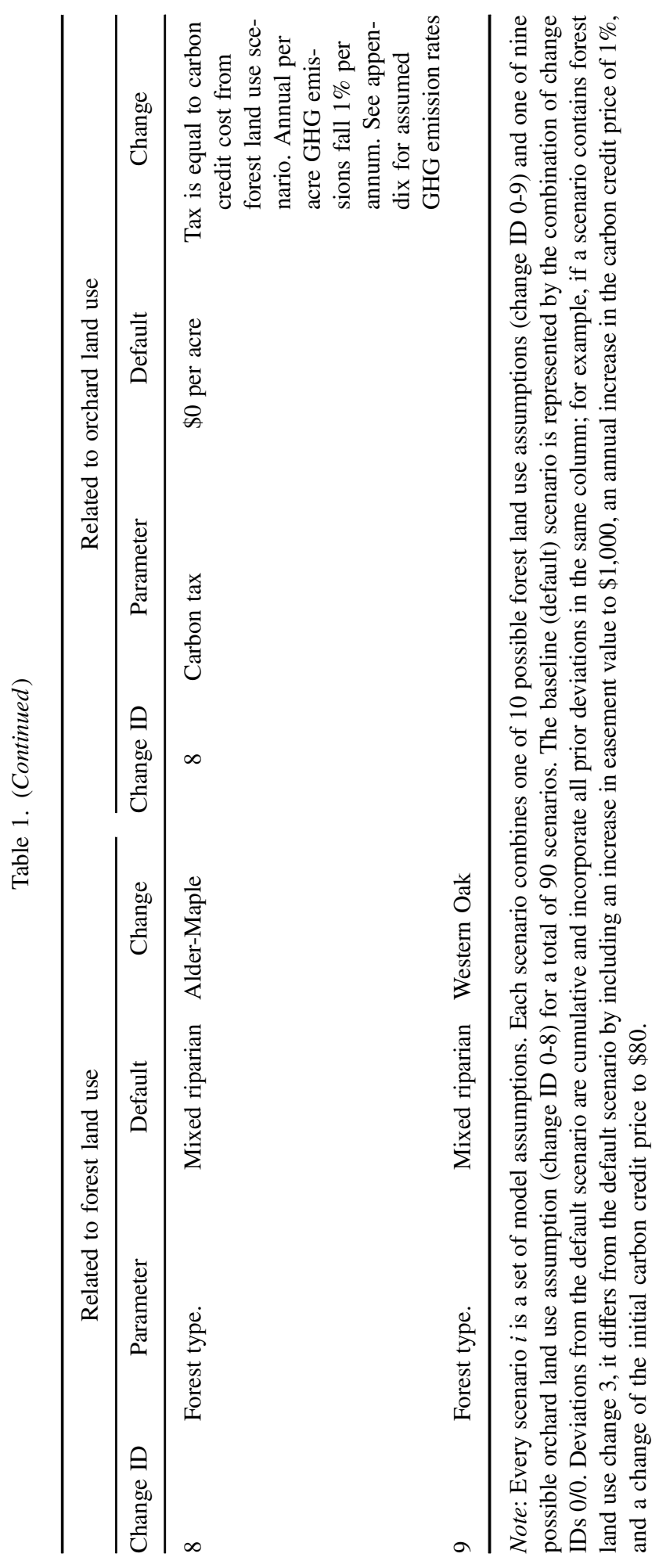


Program land in central California. Alternatively, we consider a slightly lower tree establishment cost of $\$ 737.76$ acre $^{-1}$ at any $t$ (Matzek et al., 2015). This last number is based on recent tree restoration projects on abandoned agricultural land in the Sacramento River valley. Forest establishment costs are part of the $c_{5 t(1)}$ term in Eq. (1).

Once the farmer has established a forest on her land, compliance with CARB's offset protocol for forest projects must be intermittently verified for offset credits to be issued. There is an initial verification and then a sequence of verifications every few years after that. The timing of the initial verification affects the sequence of later verifications. Further, because the farmer cannot be given credits until a verification has taken place, the timing of the initial verification also affects the sequence of credit allocation; the earlier the initial verification, the earlier the farmer earns credits. Conversely, the advantage of a later initial verification is greater tree growth, and therefore more credits, at the first allocation. By default we assume the initial verification takes place 10 years after forest establishment $(s=10)$ and verifications cost as estimated in a pro-forma calculation tool (Saah et al., 2012). We alternatively consider an initial verification four years after forest establishment $(s=4)$ or an initial verification four years after forest establishment and verification costs that are $50 \%$ of the pro-forma estimates. Verification costs are part of the cost term $c_{5 t(s)}$ and contribute nothing to the cost term in the years with no verification.

We also tested whether the forest land use decision was sensitive to the type of forest established on the farm. Typically, habitat restoration on former farmland in this region aims to replant mixed riparian forest, and we default to that forest type in most scenarios. (See Matzek et al. (2015) for a list of tree species found in these forests and their rate of carbon accumulation in the three pools that can be used to earn carbon credits in forest offset projects in California: live tree, standing dead tree pool, and understory pools.) Other forest types differ from mixed riparian in the rate and timing of carbon accumulation, and therefore will change the carbon credit accumulation trajectory. Forest land use scenarios 8 and 9 examine the influence of restoring AlderMaple or Western Oak forests on the farmer's land (Smith et al., 2005).

The final forest land use assumption that we include in our scenario analysis is the offset project leakage rate. When a famer uses her land for forest instead of crop production the foregone commodity production may be displaced to another piece of land, resulting in that land's release of its stored carbon, and novel emissions from fossil fuels used to work that land. To compensate for this possible "leakage," CARB reduces the credits earned from a forestry offset by $24 \%$. We alternatively consider a leakage rate of $0 \%$ to simulate a hypothetical policy change that would exempt small farmers from the leakage penalty.

Now we describe the ways we vary orchard and pasture land use assumptions (socalled orchard land use scenarios). As a default we assume that fertilizer prices do not change over time. However, an extrapolation of real fertilizer price trends beginning in 1981 suggests that that real price of fertilizer, on average, will continue to fall $0.67 \%$ 
per annum (USDA, 2013). ${ }^{4}$ Therefore, as an alternative, we assume all fertilizer costs — part of the cost term $c_{j t(s)}$ for $j=1,2,3,4$ - will fall from their initial price by $0.67 \%$ per annum across all $t$.

As a default we assume that capital costs on the farm do not change over time. However, the cost of capital recovery of farm machinery and equipment has increased steadily since 2001; for example, $1.35 \%$ per annum on US corn farms (USDA, 2015). Capital recovery cost is an estimate of the cost of replacing the capital investment in machinery and equipment that is used up in the annual production process. Therefore, as an alternative, we assume all capital costs, summarized in the cost term $k_{j t}$, will increase $1.35 \%$ per annum across all $t$ for $j=1,2,3,4$.

We also experiment with increasing the cost of irrigation water and beehive rental. The recent drought in California has increased water scarcity in the Sacramento River valley and its farmers have been forced to accept cuts in their allotments of surface water. In response to the drought crisis there is increasing pressure to dramatically increase the price of irrigation water. In the orchard and pasture enterprise budgets used in this analysis the average cost of an acre-inch of irrigation water is $\$ 4.65$. We alternatively consider a price of $\$ 15$ across all $t$ or a price of $\$ 15$ at $t=0$ and $1 \%$ growth per annum. ${ }^{5}$ Further, the recent bee colony collapse epidemic suggests that beehives might become more expensive to rent (Sumner and Boriss, 2006), both due to increased costs to bee-keepers and hive scarcity. In the budgets used in this analysis the average cost of beehive rental is $\$ 140 \mathrm{acre}^{-1}$ in almond orchards and $\$ 15 \mathrm{acre}^{-1}$ in prune orchards. In the scenario analysis we alternatively consider a rental price of $\$ 280$ acre $^{-1}$ across all $t$ for almond orchards and $\$ 30$ acre $^{-1}$ across all $t$ for prune orchards or a rental price of $\$ 280 \mathrm{acre}^{-1}$ at $t=0$ for almond orchards and $\$ 30 \mathrm{acre}^{-1}$ at $t=0$ for prune orchards and $1 \%$ growth per annum in the rental cost for both orchard types. Irrigation costs are part of the cost term $c_{j t(s)}$ for $j=1,2,3,4$ and beehive rental costs are part of the cost term $c_{j t(s)}$ for $j=1,3$.

We also experiment with alternative crop yields. According to the enterprise budget we used to calculate almond orchard costs, almond yields are $0,0,400,800,1,600$, and 2,000 pounds acre ${ }^{-1}$ in rotation years $s=1,2,3,4,5$, and 6 through 25, respectively. When we extrapolate historical almond yields beginning in 1919 to 2111 (100 years after 2011) yield is 3,700 pounds acre ${ }^{-1}$. Therefore, in the scenario analysis we consider a $0.6 \%$ per annum increase in almond yield. ${ }^{6}$ According to the enterprise budget sheet we used to calculate walnut orchard costs, walnut yields are $0,0,0,600$, $1,200,2,400,5,000$, and 6,000 pounds acre ${ }^{-1}$ in rotation years $s=1,2,3,4,5,6$, and

\footnotetext{
${ }^{4}$ The real price of nitrogen solutions $(30 \%)$ is extrapolated to fall $0.81 \%$ per annum. The real price of urea $44-46 \%$ nitrogen is extrapolated to fall $0.78 \%$ per annum. The real price of super-phosphate $44-46 \%$ phosphate is extrapolated to fall $0.41 \%$ per annum. The average is a fall of $0.67 \%$ per annum. See Supplementary Materials for more details. ${ }^{5}$ Even if the real price of irrigation water does not increase, farmers in the Sacramento Valley may cope with reduced water allocations by investing in wells to pump groundwater. In this case, the increase in the cost of irrigation water is a stand-in for the cost increase due to additional well development.

6If we use a yield of 2000 in $t=0$ then $2000(1.006)^{t}$ gets us close to 3700 by $t=99$.
} 
7 through 25, respectively. When we extrapolate historical walnut yields beginning in 1920 to 2111 (100 years after 2011) yield is 6384 pounds acre ${ }^{-1}$ (NASS, 2015). Therefore, in the scenario analysis we consider a $0.065 \%$ per annum increase in walnut yield. ${ }^{7}$ The prune, wheat, and pasture enterprise budgets assume yields that, according to extrapolated historical data of central California yields, will not be reached until the mid-21st century. Therefore yields for these crops remain as reported in the enterprise budget sheets across all $t$. This means that all scenarios we run include optimistic assumptions about prune, hay, and wheat yields in the earlier years of problem (2).

Finally, we consider the impact of a carbon tax on orchard and pasture use. Annual net GHG emissions from an acre of almond, walnut, and prune orchards are estimated to be $0.196 \mathrm{Mg} \mathrm{C}, 0.248 \mathrm{Mg} \mathrm{C}$, and $0.248 \mathrm{Mg} \mathrm{C}$, respectively (Marvinney et al., 2014). Further, annual net GHG emissions from an acre of hay and wheat production are estimated to be $0.094 \mathrm{Mg} \mathrm{C}$ and $0.051 \mathrm{Mg} \mathrm{C}$, respectively (Nelson et al., 2009). In the carbon tax scenario we assume the tax is equal to the price of a carbon credit $\left(p_{5 t}\right)$ and the farm pays $p_{5 t}$ for every net $\mathrm{Mg}$ of $\mathrm{C}$ emitted in year $t$. We also assume that net emissions fall by $1 \%$ per annum. For example, on an almond orchard where 40 acres of the 100 acre farm are in almond production and the other 60 acres are in annual wheat production the carbon tax is equal to $p_{5 t}\left[\left(40 \times 0.196(0.99)^{t}\right)+\left(60 \times 0.051(0.99)^{t}\right)\right]$ in year $t$. A carbon tax is part of the cost term $c_{j t(s)}$ for $j=1,2,3,4$.

\section{Results}

Our representative farmer is not likely to find it in her best interest to commit to a perpetual forest at any point (Fig. 1). The likelihood that the farmer chooses

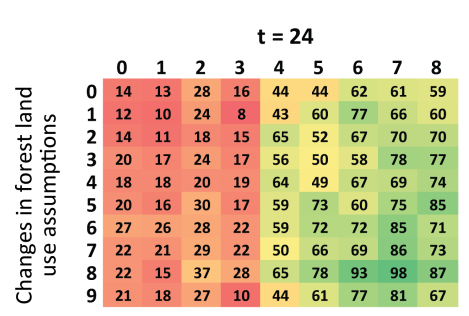

(a)

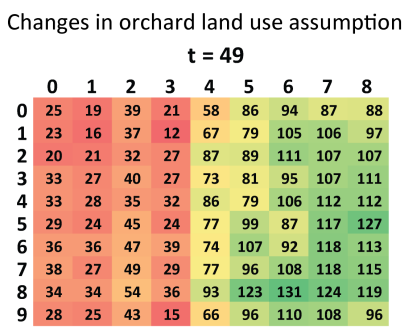

(b)

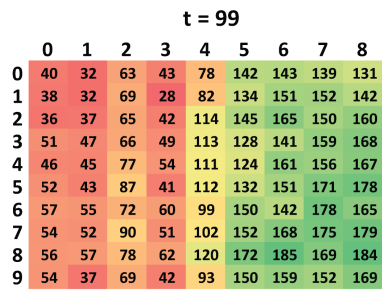

(c)

Note: Each cell indicates number of times in a scenario simulation that the farmer selects irreversible tree farming as of time step $t$. Recall each scenario generates 1000 optimal land use trajectories for the farm. The rows indicate forest land use assumption change IDs (Table 1) and the columns indicate orchard land use change IDs (Table 1). A row and column combination forms a scenario. The color scale is unique to each time step. For example, all scenario results at time step $t=24$ are placed on their own color scale, all scenario results at time step $t=49$ are placed on their own color scale, etc. Dark red indicates relatively little selection of irreversible tree farming and dark green indicates relatively heavy selection of irreversible tree farming. Yellow is the intermediate color.

Figure 1. Scenario results.

${ }^{7}$ If we use a yield of 6000 in $t=0$ then $2000(1.00065)^{t}$ gets us close to 6384 by $t=99$. 
reforestation at some point over the first 100 years ranges from $2.8 \%$ to $18.5 \%$. Generally, varying the assumptions related to the costs and yields from orchard and pasture farming had a larger effect on the likelihood of adopting the reforestation option than varying assumptions related to the cost of forest land use, the structure of the offset program, or carbon credit prices. In summary, the tripling of the cost of irrigation water does the most to encourage conversion to carbon farming, while an increase in orchard yields over time most discourages carbon farming. Among the assumptions concerning forest land use, the likelihood of conversion to forest was most sensitive to the type of forest planted.

The likelihood of carbon farming being a solution to (2) increased the most when the cost of an acre-inch of irrigation water went from $\$ 4.65$ for all $t$ to $\$ 15.00$ for all $t$ (the '4-3' column of Figs. 2(a)-2(c)). On average, across all forest land use assumptions, the number of conversions to carbon farming as of $t \leq 99$ goes up by 55.2 when the cost of irrigation water increased threefold (the average of the '4-3' column of Fig. 2(c)). Adding a 1\% per annum increase to the aforementioned bump in the cost of irrigation water has the second largest positive impact on the adoption of carbon farming (the average of the ' $5-4$ ' column of Fig. 2(c) is 40.5). Using higher almond and walnut yields in the model does the most to reduce the likelihood of forest land use (the '3-2' column in Figs. 2(a)-2(c)). Finally, penalizing agricultural activities by subjecting their GHG emissions to a carbon tax had a negligible effect on conversion to forest land use in the first half of our simulated century. Only in the later years of the simulation does a carbon tax begin to (marginally) tilt land use choice towards forestry

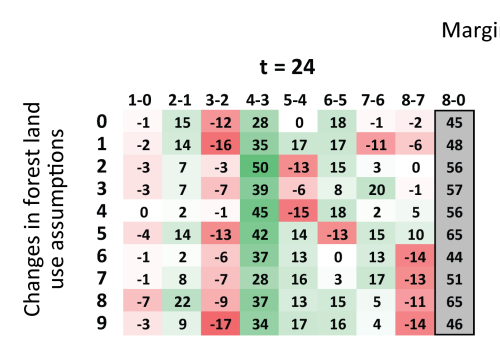

(a)
Marginal impact of changes in orchard land use assumptions

$\mathbf{t}=\mathbf{4 9}$

\begin{tabular}{|cccccccccc|c|} 
& $1-0$ & $2-1$ & $3-2$ & $4-3$ & $5-4$ & $6-5$ & $7-6$ & $8-7$ & $8-0$ \\
\hline 0 & -6 & 20 & -18 & 37 & 28 & 8 & -7 & 1 & 63 \\
1 & -7 & 21 & -25 & 55 & 12 & 26 & 1 & -9 & 74 \\
2 & 1 & 11 & -5 & 60 & 2 & 22 & -4 & 0 & 87 \\
3 & -6 & 13 & -13 & 46 & 8 & 14 & 12 & 4 & 78 \\
4 & -5 & 7 & -3 & 54 & -7 & 27 & 6 & 0 & 79 \\
5 & -5 & 21 & -21 & 53 & 22 & -12 & 30 & 10 & 98 \\
6 & 0 & 11 & -8 & 35 & 33 & -15 & 26 & -5 & 77 \\
7 & -11 & 22 & -20 & 48 & 19 & 12 & 10 & -3 & 77 \\
8 & 0 & 20 & -18 & 57 & 30 & 8 & -7 & -5 & 85 \\
9 & -3 & 18 & -28 & 51 & 30 & 14 & -2 & -12 & 68 \\
\hline
\end{tabular}

(b) $\mathbf{t}=99$

\begin{tabular}{|c|c|c|c|c|c|c|c|c|c|} 
& $1-0$ & $2-1$ & $3-2$ & $4-3$ & $5-4$ & $6-5$ & $7-6$ & $8-7$ & $8-0$ \\
\hline 0 & -8 & 31 & -20 & 35 & 64 & 1 & -4 & -8 & 91 \\
1 & -6 & 37 & -41 & 54 & 52 & 17 & 1 & -10 & 104 \\
\hline 2 & 1 & 28 & -23 & 72 & 31 & 20 & -15 & 10 & 124 \\
3 & -4 & 19 & -17 & 64 & 15 & 13 & 18 & 9 & 117 \\
4 & -1 & 32 & -23 & 57 & 13 & 37 & -5 & 11 & 121 \\
\hline 5 & -9 & 44 & -46 & 71 & 20 & 19 & 20 & 7 & 126 \\
6 & -2 & 17 & -12 & 39 & 51 & -8 & 36 & -13 & 108 \\
7 & -2 & 38 & -39 & 51 & 50 & 16 & 7 & 4 & 125 \\
8 & 1 & 21 & -16 & 58 & 52 & 13 & -16 & 15 & 128 \\
9 & -17 & 32 & -27 & 51 & 57 & 9 & -7 & 17 & 115 \\
\hline
\end{tabular}

(c)

Note: Each cell indicates the difference in the number of times the farmer selects irreversible tree farming as of time step $t$ across incremental change in orchard land use assumptions holding the changes in forest land use assumptions constant. The rows indicate the forest land use assumption change IDs (Table 1) and the columns indicate the assumption change particular to an orchard land use change ID (Table 1). For example, column 1-0 isolates the impact of the annual $1 \%$ decline in fertilizer costs on scenario results. Or, column 2-1 isolates the impact of the annual $1.35 \%$ increase in capital costs given the previous change in annual fertilizer costs, etc. The color scale is unique to each time step. Dark red indicates a relatively large decrease in the selection of irreversible tree farming and dark green indicates a relatively large increase in the selection of irreversible tree farming. White is the intermediate color and is associated with a change of 0 . The gray column gives the total gain in irreversible tree farming across the incremental changes in orchard land use assumptions.

Figure 2. Marginal effect of changes in orchard land use assumptions. 


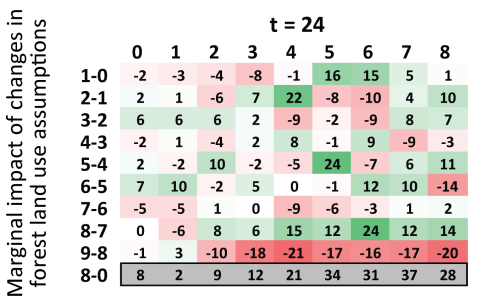

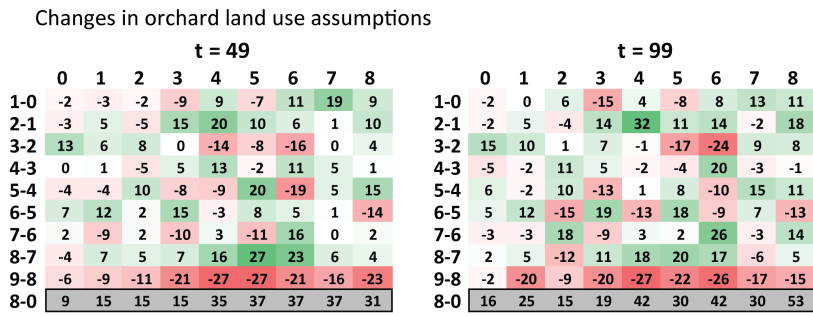

Note: Each cell indicates the difference in the number of times the farmer selects irreversible tree farming as of time step $t$ across incremental change in forest land use assumptions holding the changes in orchard land use assumptions constant. The rows indicate assumption change particular to a forest land use change ID (Table 1) and the columns indicate the orchard land use change IDs (Table 1). For example, row 1-0 isolates the impact of the change in the value of a carbon offset from $\$ 41.58$ to $\$ 80.00$ on scenario results. Or, row 2-1 isolates the impact of the annual $1 \%$ increase in the value of an offset given the previous change in an offset's initial value, etc. The color scale is unique to each time step. Dark red indicates a relatively large decrease in the selection of irreversible tree farming and dark green indicates a relatively large increase in the selection of irreversible tree farming. White is the intermediate color and is associated with a change of 0 . The gray row gives the total gain in irreversible tree farming across the incremental changes in forest land use assumptions up to change ID 8 .

Figure 3. Marginal effect of changes in forest land use assumptions.

and away from prune use. (Prune orchards have a higher rate of carbon emissions than the other two orchard uses.)

Generally, the changes in forest land use assumptions (the rows of Figs. 3(a)-3(c)) did little to increase the likelihood of converting orchards or pasture to forest. Among these assumptions, changes in forest type are generally the most influential, with a shift to a more productive Alder-Maple forest producing the largest increase in likelihood of conversion to carbon farming as of $t \leq 49$ (rows '8-7' of Figs. 3(a) and 3(b)), and a shift to Western Oak forest producing the largest decrease (rows '9-8' of Figs. 3(a) and 3(b)). Western Oak forest had the lowest carbon accumulation rate of the three forest types throughout the modeled timeframe, while mixed riparian had the highest growth in the early years of establishment $(s \leq 15)$ and Alder-Maple had the highest growth in later years $(s \geq 15)$. Alder-Maple's late-term growth advantage appears to be responsible for its greater influence on forest land use adoption after $t=24$. A $1 \%$ per annum increase in the price of a carbon credit (row ' $2-1$ ' in Figs. 3(a)-3(c)), the removal of the leakage penalty (row ' $6-5$ ' in Figs. 3(a)-3(c)), and the reduction in the cost of carbon credit verifications (row '5-4' in Figs. 3(a)-3(c)) are the next three most impactful changes among forest land use assumptions. Somewhat surprisingly, an immediate doubling of credit price had little effect on the likelihood of forest use (row '1-0' in Figs. 3(a)-3(c)).

The fact that changes to the orchard land use assumptions had a greater positive impact on carbon farming conversion than the forest land-use assumptions is most clearly seen in the cumulative impact figures (gray column 8-0 in Figs. 2(a)-2(c); gray row 8-0 in Figs. 3(a)-3(c), which sum up the net impact of each type of change. The average net change in conversion to carbon credits due to orchard land-use assumptions is +5.33 , +7.86 , or +11.6 percentage points at time steps $t=24, t=49$, and 
$t=99$, respectively; the corresponding figures for forest land-use assumptions are only $+2.02,+2.57$, and +2.72 percentage points. ${ }^{8}$

In a few cases the farmer adopts forest use immediately. This occurs if orchard commodity prices fall immediately and never recover or recover much later (when the

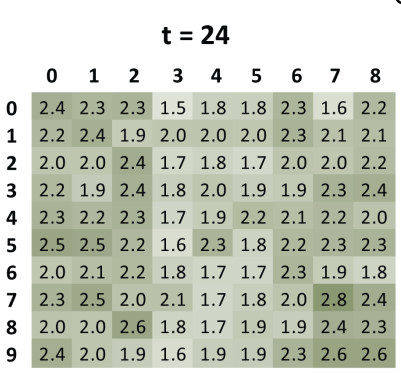

$\begin{array}{lllllllllll}0 & 3.0 & 3.1 & 2.5 & 1.8 & 2.4 & 2.4 & 2.4 & 2.5 & 2.9\end{array}$

$\begin{array}{llllllllllll}1 & 2.8 & 2.5 & 2.2 & 2.4 & 2.4 & 2.3 & 2.7 & 3.0 & 2.7\end{array}$

$\begin{array}{llllllllllll}2 & 2.8 & 2.6 & 2.8 & 2.2 & 2.2 & 2.2 & 2.6 & 2.6 & 2.9\end{array}$

$\begin{array}{llllllllllll}3 & 2.5 & 2.5 & 2.8 & 2.1 & 2.7 & 2.3 & 2.5 & 2.9 & 3.1\end{array}$

$\begin{array}{lllllllllllll}4 & 3.2 & 2.6 & 3.1 & 2.3 & 2.3 & 2.3 & 2.5 & 2.7 & 2.5\end{array}$

$\begin{array}{lllllllllllll}5 & 2.8 & 2.9 & 2.8 & 2.1 & 2.9 & 2.1 & 3.0 & 2.5 & 3.0\end{array}$

$\begin{array}{llllllllllll}6 & 2.3 & 2.7 & 2.5 & 2.3 & 2.3 & 2.3 & 2.9 & 2.2 & 2.3\end{array}$

$\begin{array}{lllllllllllll}7 & 3.1 & 3.0 & 2.8 & 2.6 & 2.2 & 2.2 & 2.6 & 2.9 & 2.9\end{array}$

$\begin{array}{lllllllllllll}8 & 2.8 & 2.5 & 3.0 & 1.9 & 2.4 & 2.6 & 2.5 & 3.7 & 2.9\end{array}$

\begin{tabular}{llll|l|l|l|l|l|l|l|}
9 & 2.8 & 2.4 & 2.6 & 2.0 & 2.3 & 2.5 & 3.0 & 3.1 & 3.2
\end{tabular}

$\begin{array}{lllllllllll}0 & 0.1 & 0.1 & 0.1 & 0.1 & 0.1 & 0.0 & 0.0 & 0.0 & 0.0\end{array}$

$\begin{array}{lllllllllll}1 & 0.1 & 0.1 & 0.1 & 0.1 & 0.0 & 0.0 & 0.0 & 0.0 & 0.0\end{array}$

$\begin{array}{llllllllll}2 & 0.1 & 0.1 & 0.1 & 0.1 & 0.0 & 0.0 & 0.1 & 0.0 & 0.0\end{array}$

$\begin{array}{llllllllll}3 & 0.1 & 0.1 & 0.1 & 0.1 & 0.0 & 0.0 & 0.1 & 0.0 & 0.0\end{array}$

$\begin{array}{lllllllllll}4 & 0.1 & 0.1 & 0.1 & 0.1 & 0.0 & 0.1 & 0.0 & 0.0 & 0.0\end{array}$

$\begin{array}{lllllllllll}5 & 0.1 & 0.1 & 0.1 & 0.1 & 0.1 & 0.0 & 0.0 & 0.1 & 0.0\end{array}$

$\begin{array}{lllllllllll}6 & 0.1 & 0.1 & 0.1 & 0.1 & 0.0 & 0.0 & 0.0 & 0.0 & 0.0\end{array}$

$\begin{array}{llllllllll}7 & 0.1 & 0.1 & 0.1 & 0.1 & 0.0 & 0.0 & 0.0 & 0.0 & 0.0\end{array}$

$8 \begin{array}{llllllllll}8 & 0.1 & 0.1 & 0.1 & 0.1 & 0.0 & 0.0 & 0.0 & 0.1 & 0.0\end{array}$

$\begin{array}{llllllllllll}9 & 0.1 & 0.1 & 0.1 & 0.1 & 0.0 & 0.0 & 0.0 & 0.0 & 0.0\end{array}$

$\begin{array}{llllllllll}0 & 0.1 & 0.1 & 0.2 & 0.1 & 0.2 & 0.2 & 0.4 & 0.3 & 0.4\end{array}$

$\begin{array}{llllllllll}1 & 0.1 & 0.1 & 0.1 & 0.0 & 0.2 & 0.3 & 0.5 & 0.4 & 0.4\end{array}$

$\begin{array}{llllllllllll}2 & 0.1 & 0.1 & 0.1 & 0.1 & 0.3 & 0.3 & 0.4 & 0.4 & 0.5\end{array}$

$\begin{array}{lllllllllll}3 & 0.1 & 0.1 & 0.2 & 0.1 & 0.3 & 0.3 & 0.3 & 0.5 & 0.5\end{array}$

$\begin{array}{llllllllll}4 & 0.1 & 0.1 & 0.1 & 0.1 & 0.4 & 0.3 & 0.4 & 0.4 & 0.4\end{array}$

$\begin{array}{llllllllll}5 & 0.1 & 0.1 & 0.2 & 0.1 & 0.4 & 0.4 & 0.4 & 0.5 & 0.6\end{array}$

$6 \begin{array}{llllllllll}6 & 0.1 & 0.2 & 0.2 & 0.1 & 0.3 & 0.4 & 0.5 & 0.5 & 0.4\end{array}$

$\begin{array}{llllllllllll}7 & 0.1 & 0.1 & 0.2 & 0.1 & 0.3 & 0.4 & 0.4 & 0.6 & 0.5\end{array}$

$\begin{array}{llllllllllll}8 & 0.1 & 0.1 & 0.3 & 0.1 & 0.4 & 0.5 & 0.6 & 0.8 & 0.6\end{array}$

$\begin{array}{lllllllllllll}9 & 0.1 & 0.1 & 0.2 & 0.0 & 0.2 & 0.4 & 0.5 & 0.6 & 0.5\end{array}$

Changes in orchard land use assumptions

$$
\mathbf{t}=\mathbf{4 9}
$$

\begin{abstract}
$\begin{array}{lllllllll}0 & 1 & 2 & 3 & 4 & 5 & 6 & 7 & 8\end{array}$
$\begin{array}{lllllllll}2.0 & 1.8 & 1.9 & 1.0 & 1.1 & 1.3 & 1.4 & 1.2 & 1.3\end{array}$ \begin{tabular}{ll|l|l|l|l|l|l|l}
1.8 & 2.2 & 1.5 & 1.0 & 1.0 & 1.1 & 1.6 & 1.3 & 1.3
\end{tabular} $\begin{array}{lllllllll}1.9 & 2.0 & 1.9 & 1.2 & 1.1 & 0.9 & 1.1 & 1.4 & 1.4\end{array}$ $\begin{array}{lllllllll}1.7 & 1.7 & 1.7 & 1.3 & 1.2 & 1.1 & 1.2 & 1.5 & 1.5\end{array}$ $\begin{array}{lllllllll}2.0 & 1.5 & 1.6 & 1.1 & 1.1 & 1.4 & 1.4 & 1.4 & 1.4\end{array}$ $\begin{array}{lllllllll}2.1 & 2.1 & 1.6 & 1.1 & 1.1 & 1.2 & 1.4 & 1.4 & 1.4\end{array}$ $\begin{array}{llllllllll}2.0 & 1.8 & 1.8 & 1.1 & 1.0 & 1.2 & 1.6 & 1.1 & 1.2\end{array}$ $\begin{array}{lllllllllll}1.8 & 1.9 & 1.8 & 1.1 & 1.2 & 1.2 & 1.3 & 1.7 & 1.4\end{array}$ $\begin{array}{llllllllll}1.7 & 2.2 & 1.8 & 1.1 & 1.1 & 1.2 & 1.2 & 1.7 & 1.5\end{array}$ $\begin{array}{lllllllll}2.1 & 1.9 & 1.7 & 1.1 & 1.1 & 1.2 & 1.3 & 1.4 & 1.4\end{array}$
\end{abstract}

\begin{abstract}
$\begin{array}{lllllllll}2.7 & 2.6 & 2.2 & 1.2 & 1.6 & 1.6 & 1.6 & 1.7 & 1.9\end{array}$ $\begin{array}{lllllllllll}2.5 & 2.4 & 1.9 & 1.5 & 1.3 & 1.5 & 2.0 & 1.8 & 1.8\end{array}$ $\begin{array}{llllllllll}2.5 & 2.2 & 2.2 & 1.5 & 1.5 & 1.4 & 1.6 & 1.7 & 2.0\end{array}$ $\begin{array}{llllllllll}2.2 & 2.2 & 2.3 & 1.6 & 1.6 & 1.6 & 1.7 & 1.9 & 2.0\end{array}$ $\begin{array}{llllllllll}2.8 & 2.1 & 2.2 & 1.3 & 1.5 & 1.8 & 1.6 & 1.8 & 1.8\end{array}$ $\begin{array}{llllllllll}2.3 & 2.3 & 2.1 & 1.4 & 1.5 & 1.6 & 1.8 & 1.8 & 1.9\end{array}$ \begin{tabular}{lllllll|l|l|l}
2.2 & 2.1 & 2.1 & 1.6 & 1.4 & 1.7 & 2.0 & 1.4 & 1.5
\end{tabular} $\begin{array}{llllllllll}2.5 & 2.5 & 2.2 & 1.4 & 1.5 & 1.4 & 1.7 & 2.1 & 1.6\end{array}$ \begin{tabular}{llll|lllll|l|l}
2.2 & 2.5 & 2.4 & 1.4 & 1.4 & 1.7 & 1.6 & 2.4 & 1.8
\end{tabular} $\begin{array}{llllllllll}2.6 & 2.0 & 2.3 & 1.4 & 1.5 & 1.9 & 1.6 & 2.0 & 1.8\end{array}$
\end{abstract}

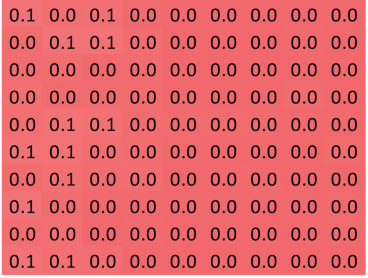

$\begin{array}{lllllllll}0.1 & 0.1 & 0.2 & 0.1 & 0.2 & 0.4 & 0.4 & 0.4 & 0.4\end{array}$ $\begin{array}{lllllllll}0.1 & 0.1 & 0.2 & 0.0 & 0.2 & 0.3 & 0.5 & 0.5 & 0.4\end{array}$ $\begin{array}{lllllllllll}0.1 & 0.1 & 0.2 & 0.1 & 0.3 & 0.3 & 0.5 & 0.5 & 0.5\end{array}$ $\begin{array}{llllllllll}0.2 & 0.1 & 0.2 & 0.1 & 0.3 & 0.3 & 0.4 & 0.5 & 0.6\end{array}$ $\begin{array}{lllllllll}0.2 & 0.1 & 0.2 & 0.1 & 0.3 & 0.4 & 0.5 & 0.5 & 0.5\end{array}$ $\begin{array}{lllllllllll}0.2 & 0.1 & 0.2 & 0.1 & 0.3 & 0.4 & 0.4 & 0.6 & 0.6\end{array}$ $\begin{array}{lllllllll}0.2 & 0.2 & 0.2 & 0.2 & 0.3 & 0.5 & 0.5 & 0.5 & 0.5\end{array}$ $\begin{array}{lllllllll}0.2 & 0.2 & 0.3 & 0.1 & 0.3 & 0.4 & 0.5 & 0.6 & 0.5\end{array}$ $\begin{array}{lllllllllll}0.2 & 0.2 & 0.3 & 0.1 & 0.4 & 0.5 & 0.6 & 0.7 & 0.6\end{array}$ $\begin{array}{llllllllll}0.2 & 0.1 & 0.2 & 0.1 & 0.3 & 0.4 & 0.5 & 0.5 & 0.4\end{array}$

\begin{abstract}
$\begin{array}{lllllllll}0 & 1 & 2 & 3 & 4 & 5 & 6 & 7 & 8\end{array}$
$\begin{array}{lllllllll}1.9 & 1.8 & 1.6 & 0.8 & 0.8 & 0.8 & 0.9 & 0.9 & 0.9\end{array}$ \begin{tabular}{llll|l|l|l|l|l|l}
1.8 & 1.7 & 1.5 & 0.9 & 0.8 & 1.0 & 0.9 & 0.8 & 1.0
\end{tabular} $\begin{array}{lllllllll}1.5 & 1.5 & 1.7 & 0.9 & 0.8 & 0.7 & 0.9 & 1.0 & 0.9\end{array}$ $\begin{array}{llllllllll}1.7 & 1.7 & 1.5 & 0.9 & 0.9 & 0.9 & 0.9 & 1.0 & 0.9\end{array}$ $\begin{array}{llllllllll}2.1 & 1.6 & 1.6 & 0.8 & 0.8 & 0.9 & 0.9 & 1.0 & 1.1\end{array}$ $\begin{array}{lllllllll}2.0 & 2.0 & 1.7 & 0.7 & 0.9 & 0.7 & 0.8 & 1.0 & 1.2\end{array}$ \begin{tabular}{llll|l|l|l|l|l}
1.9 & 1.5 & 1.7 & 0.8 & 0.9 & 0.8 & 1.0 & 0.8 & 0.9
\end{tabular} $\begin{array}{lllllllll}1.7 & 2.2 & 1.8 & 0.8 & 0.8 & 0.8 & 0.8 & 1.1 & 1.0\end{array}$ $\begin{array}{lllllllll}1.6 & 1.7 & 1.4 & 0.8 & 0.8 & 0.8 & 0.9 & 1.0 & 1.0\end{array}$ $\begin{array}{llllllllll}1.9 & 1.8 & 1.7 & 0.8 & 0.8 & 0.8 & 0.8 & 1.1 & 0.9\end{array}$
\end{abstract}
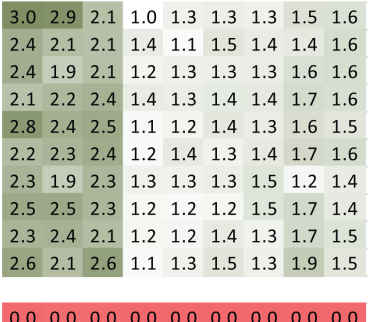
$\begin{array}{lllllllll}0.0 & 0.0 & 0.0 & 0.0 & 0.0 & 0.0 & 0.0 & 0.0 & 0.0\end{array}$ $\begin{array}{lllllllll}0.0 & 0.0 & 0.0 & 0.0 & 0.0 & 0.0 & 0.0 & 0.0 & 0.0\end{array}$ $\begin{array}{lllllllll}0.0 & 0.0 & 0.0 & 0.0 & 0.0 & 0.0 & 0.0 & 0.0 & 0.0\end{array}$ $\begin{array}{lllllllll}0.0 & 0.0 & 0.0 & 0.0 & 0.0 & 0.0 & 0.0 & 0.0 & 0.0\end{array}$ $\begin{array}{lllllllll}0.0 & 0.0 & 0.0 & 0.0 & 0.0 & 0.0 & 0.0 & 0.0 & 0.0\end{array}$ $\begin{array}{llllllllll}0.0 & 0.0 & 0.0 & 0.0 & 0.0 & 0.0 & 0.0 & 0.0 & 0.0\end{array}$ $\begin{array}{lllllllll}0.0 & 0.0 & 0.0 & 0.0 & 0.0 & 0.0 & 0.0 & 0.0 & 0.0\end{array}$ $\begin{array}{llllllllll}0.0 & 0.0 & 0.0 & 0.0 & 0.0 & 0.0 & 0.0 & 0.0 & 0.0\end{array}$ $\begin{array}{lllllllll}0.0 & 0.0 & 0.0 & 0.0 & 0.0 & 0.0 & 0.0 & 0.0 & 0.0\end{array}$

$\begin{array}{lllllllll}0.2 & 0.2 & 0.3 & 0.1 & 0.3 & 0.5 & 0.5 & 0.5 & 0.5\end{array}$ $\begin{array}{lllllllll}0.2 & 0.2 & 0.3 & 0.1 & 0.3 & 0.5 & 0.6 & 0.6 & 0.6\end{array}$ $\begin{array}{llllllllll}0.2 & 0.2 & 0.3 & 0.1 & 0.4 & 0.5 & 0.6 & 0.6 & 0.7\end{array}$ $\begin{array}{llllllllll}0.3 & 0.2 & 0.3 & 0.2 & 0.4 & 0.5 & 0.5 & 0.7 & 0.7\end{array}$ $\begin{array}{llllllllll}0.3 & 0.2 & 0.4 & 0.2 & 0.4 & 0.5 & 0.6 & 0.7 & 0.7\end{array}$ $\begin{array}{llllllllll}0.3 & 0.2 & 0.5 & 0.1 & 0.4 & 0.4 & 0.6 & 0.8 & 0.8\end{array}$ $\begin{array}{llllllllll}0.3 & 0.3 & 0.4 & 0.2 & 0.3 & 0.5 & 0.6 & 0.6 & 0.6\end{array}$ $\begin{array}{lllllllll}0.3 & 0.3 & 0.5 & 0.2 & 0.3 & 0.5 & 0.7 & 0.8 & 0.7\end{array}$ $\begin{array}{lllllllllll}0.3 & 0.3 & 0.4 & 0.2 & 0.4 & 0.7 & 0.7 & 0.8 & 0.8\end{array}$ $\begin{array}{lllllllllll}0.3 & 0.2 & 0.4 & 0.1 & 0.3 & 0.6 & 0.6 & 0.7 & 0.7\end{array}$

Note: Each cell indicates the number of times in a scenario simulation the farm was in a particular land use at $t=24$, $t=49$, and $t=99$ relative to almond land use. For example, at time $t=24$ in the default scenario $(0 / 0)$ the number of times the farm is in walnut use is 2.4 times greater than the number of times it is in almond use. Recall each scenario generates 1000 optimal land use trajectories for the farm. White indicates a 1:1 likelihood of the given land use with almond land use; values less than one (land use less likely than almonds) are shown in red and values greater than one (land use more likely than almonds) in green. The color scale is the same across all time steps and land uses.

Figure 4. Likelihood of land use.

\footnotetext{
${ }^{8}$ These figures are obtained by averaging the net cumulative impact for all orchard or forest land use assumptions at each time step (gray columns or rows in Figs. 2 and 3) and converting to percentage points from (number of carbon farming conversions/1000 model runs).
} 
present value of an orchard product is much lower due to discounting). Otherwise, forest land use becomes increasingly likely over time as commodity price variance increases and periods of very low commodity prices become more frequent. For instance, from $t=24$ to $t=99$, across all scenarios, the likelihood of forest use increases on average by $144 \%$.

In Fig. 4, we give an indication of the entire set of land use choices on this farm across all scenarios. The cells indicate the number of times the farm was in a particular land use at $t=24, t=49$, and $t=99$ relative to almond land use under each scenario simulation. In the first quarter of the 100-year simulated time span, conditions are most favorable for prunes and walnut use. By $t=49$ almond use has become slightly more competitive relative to prune and walnut use for orchard land use changes 0 through 2 (columns 0-2 of Fig. 4) and extremely competitive given land use changes 3 through 8 (columns 3-8 of Fig. 4). Recall that orchard land use changes 3 through 8 incorporate increases in the expected yield of an almond orchard over time. Finally, as forest use becomes more prevalent as $t$ approaches 99 it is most likely to come at the expense of walnuts or prune use (Fig. 4).

\section{Discussion}

Our analysis shows that forest carbon in US compliance offset markets is not valuable enough to compete with orchard products. Even when we make plausible market, biophysical, and policy changes that greatly increase the net returns to forest and significantly reduce the net returns to orchard use, a grower intent on maximizing net revenue in the Central Valley of California is highly unlikely to convert a farm to forest at any point over the next 100 years. At best, the likelihood of conversion is about $18.5 \%$ by the 99 th year (or $22.4 \%$, if we tip the balance even further toward forest land use by eliminating the possibility of orchard yield increases over time from the scenarios). Under a more reasonable set of assumptions (e.g., an increase in orchard yields over time, a decrease in fertilizer costs over time, an increase in carbon credit prices over time) the likelihood of conversion to forest is about $10.0 \%$ by the 99 th year. The likelihood given current policy and economic conditions is a mere $4.0 \%$.

In our model we assume the farmer perfectly predicts commodity prices, input costs, and changes in biophysical parameters (e.g., trends in yields). If we had cast our problem as a stochastic one where the farmer had to make a choice at each $t$ not knowing future prices, input costs, or trends in biophysical processes - a more realistic situation - optimal adoption of carbon farming would even be lower, given the positive option value from delaying the adoption of irreversible land use (Arrow and Fisher, 1974). How much impact quasi-option value will have on the adoption of irreversible forestry projects for carbon credit creation is an important question that deserves further study (Albers, 1996).

Several generalizations emerge from our analysis of detailed, realistic orchard revenue cost data and forestry offset policy guidelines. First, the likelihood of inducing 
growers in this region to convert to a forest land use is relatively insensitive to any policy changes that could plausibly be made, including (1) elimination of the leakage penalty for conversion from economically viable agricultural activities, (2) imposition of a carbon tax on agricultural activities, (3) implementing a price floor in irrigation water, and (4) paying more for a conservation easement on a reforested orchard.

To illustrate the ineffectiveness of a change in California's cap-and-trade system, consider the case of reducing the leakage penalty from $24 \%$ of earned carbon credits to 0 . In the case where the farmer selects forest use at $t=0$ and the former land use was an exhausted almond orchard, over the next 100 years the farm generates an additional $\$ 10,405$ in discounted net revenue due to the change in leakage policy. Compare this to a situation where the farmer chooses almond farming for all 100 years. Over 10 iterations of the default scenario, the average discounted net revenue from 100 years of almond farming is $\$ 2,749,214$. The value added from dropping the leakage rate to 0 is only $0.378 \%$ of this value. In other words, eliminating the leakage penalty is an insignificant change compared to the revenues possible from continuing the most lucrative agricultural activity.

Similarly, adding small farms to the list of industries subject to a carbon tax might also be expected to increase substantially the likelihood of conversion from agriculture to carbon credits, but the actual effect of the carbon tax in the model was negligible for two reasons: first, the tax is swamped by other costs associated with farming; and second, orchards have relatively little climate change impact because they sequester significant amounts of carbon in their woody biomass. For an illustration, assume all default inputs except a newly imposed carbon tax of $41.58 \mathrm{Mg}^{-1} \mathrm{C}$. In this case annual operational costs (not including capital and clearing costs) on an almond orchard, walnut orchard, prune orchard, and a pasture increase on average by a mere $0.396 \%$, $0.575 \%, 0.417 \%$, and $0.873 \%$, respectively.

The second broad generalization is that increases in the cost of producing agricultural commodities will be more likely to turn farmers toward carbon credits in this region. We modeled increases in irrigation costs because drought is already a periodic constraint on California agriculture, because climate change promises to increase the frequency, duration, and severity of droughts, and because the current severe drought threatens to change the pricing structure of surface water to agricultural users in the state. However, water costs would probably need to increase by an order of magnitude to result in the conversion of significant numbers of agricultural parcels to forest, since a tripling of the existing water cost in our model had only a modest effect on the likelihood of adopting forest carbon as a land use. Also, if water costs increased to that extent, growers might adapt by changing irrigation practices (e.g., to drip irrigation) or by changing to less water-intensive cropping, rather than to forest.

A third generalization is that carbon prices are much too low to compete with commodity prices. This leads us to two separate conclusions about how to encourage reforestation. First, participation in a carbon program might be more attractive if forests were to replace low-value agricultural activities like grazing, rather than lucrative fruit 
and nut orchards. Not only are the net returns to grazing relatively low compared to orchard agriculture, but more carbon credits would be earned on grazing land, all else equal, due to the absence of baseline carbon sequestration (orchards sequester quite a bit of carbon, and therefore, the additional carbon stored in forests on former orchards the basis for credits - is relatively lower). However, qualifying forest offset projects must occur on lands formerly occupied by a minimum of $10 \%$ forest canopy cover, which is unlikely to be true of arid or semi-arid lands currently used for grazing. Wetter riparian areas within grazing lands, and places where agricultural land values are declining or agricultural activities being abandoned, may be fertile ground for landowner participation in the carbon market. Second, there are institutional changes that would increase demand for credits and therefore their price. For instance, expansion of the capand-trade program to regulate more emitters, a decrease in the cap that limits emissions, or a requirement that credits purchased by California emitters be earned in California, would all drive up the credit price for our representative farmer. However, we are skeptical that incremental efforts to increase demand would encourage widespread adoption of carbon farming. To demonstrate this we re-ran the default scenario at credit prices that ranged from $\$ 0$ to $\$ 8,000$ (Fig. 5). Only at a credit price of approximately $\$ 3,500$ did the likelihood of adopting carbon farming by $t=99$ reach $50 \%$.

We have presented a pessimistic view of the use of the US regional cap-and-trade programs for reforestation on cleared agricultural land. Actual participation in the program backs up this pessimism. To date, no reforestation credits have been earned in either the CARB or ReGGIe program. As of May 2016, ReGGIe had no forest projects registered at all. Of the approximately 120 forest projects listed with CARB, all but a

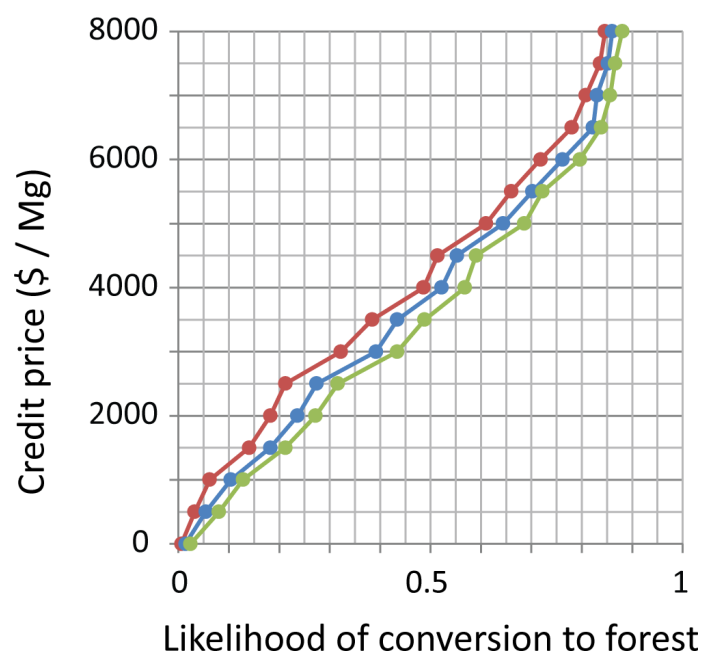

Note: The curves indicate the likelihood of conversion to forest use as a function of carbon credit price as $t=0$ (red), as of $t=49$ (blue), and as of $t=99$ (green). These supply curves come from a simulation of the default scenario, modified so that the price of a carbon credit varies from $\$ 0$ to $\$ 8,000$ instead of being fixed at $\$ 41.58$.

Figure 5. Forest use supply curve. 
few were aimed at increasing carbon sequestration through other land use changes (improved forest management or avoided deforestation), not reforestation. This suggests that companies in the timber and forest products sector are the landowners currently benefiting from forest offset projects under CARB and that reforesting cleared land is not economically appealing.

All of this does not necessarily mean that small farmers will not participate in the carbon market. Occasionally landowners make land use choices that do not conform to the predictions of net revenue maximizing models. Instead landowners may choose to maximize a utility function that includes a mix of values and desires, including land stewardship and conservation (Sorice et al., 2011; Reimer et al., 2012; Rodriguez et al., 2012; De Snoo et al., 2013). For orchard owners who place a high value on land stewardship or who wish to use a conservation easement to prevent their land from eventually being converted to nonagricultural development, reforestation may be attractive in spite of the relatively weak economic returns from carbon credits. For this class of landowners, two approaches to increasing carbon farming might be effective, one based in policy, and the other in outreach.

On the policy side, minimizing the hassle of converting to carbon farming, by offering technical assistance (Sorice et al., 2011) or by reducing the measurement, verification, and reporting costs of earning credits, could increase landowner participation. Tax incentives that eliminate property and estate taxes on converted parcels, or allow carbon credit income to be earned tax-free, might also increase forest conversion.

Program participation might also be bolstered by outreach efforts that incorporate emerging behavioral economic understanding on how people make resource use decisions. For example, some economics experiments have demonstrated that people are less willing to undergo a task they perceive as laudatory if they are paid to do it (Kamenica, 2012). In other words, focusing on the money "prime" of a carbon farming decision, instead of the social rewards of forest conversion, may reduce the altruism and increase the social distance of potentially interested farmers. This effect is illustrated in the finding that some New Brunswick forest lot owners preferred nonmonetary incentives for continuing sustainable forest use, such as a scorecard system that recognized landowners for their good management, over monetary rewards (Quartuch and Beckley, 2014). Others worry that the existence of (small) private payments might crowd out farmers' pro-social interest in conservation and land stewardship (Cardenas et al., 2000). Given this risk, and rather paltry private economic rewards stemming from the carbon market, forest conversion by small landholders may depend on the success of an outreach message focused on the social rewards.

Researchers have also found that social networks are important in landowner decision-making processes (Knoot and Rickenbach, 2011). For example, among central Massachusetts foresters, decisions were more influenced by peer landowners and professionals than by relatives, friends, and neighbors, leading to a conclusion that outreach programs could be extended by incorporating exchanges with these "influentials" (Kittredge et al., 2013). Similarly, landowner networks were found to be an effective 
alternative to government outreach in engaging forest owners in educational and planning activities (Kueper et al., 2013). If "influentials" in central California could be persuaded to convert to forest use, the subsequent adoption of forest land use among neighboring landowners would likely be higher than our model predicts.

In sum, if conversion of more agricultural parcels to permanent forest is a desirable outcome, policies and outreach will likely need to target farmers whose agricultural activities are already of low or declining value, or whose personal preferences are to preserve their land as open space in perpetuity.

\section{Acknowledgments}

We are grateful to Peter Kareiva and Marc Conte for input on an early draft of this manuscript, as well as three anonymous reviewers whose comments greatly improved the paper. Funding for this work came from USDA grant \#CALW-2012-00882 (Matzek) and from the BECC (Biodiversity and Ecosystem Services in a Changing Climate) strategic research area at Lund University (Nelson).

\section{References}

Abbott, PC, C Hurt and WE Tyner (2011). What's driving food prices in 2011? Issue Report, Farm Foundation. Available at https://www.farmfoundation.org/news/articlefiles/105-FoodPrices_web.pdf.

Albers, HJ (1996). Modeling ecological constraints on tropical forest management: Spatial interdependence, irreversibility, and uncertainty. Journal of Environmental Economics and Management, 30, 73-94.

Antle, J, S Capalbo, S Mooney, E Elliott and K Paustian (2003). Spatial heterogeneity, contract design, and the efficiency of carbon sequestration policies for agriculture. Journal of Environmental Economics and Management, 46, 231-250.

Arrow, KJ and AC Fisher (1974). Environmental preservation, uncertainty, and irreversibility. The Quarterly Journal of Economics, 88, 312-319.

Baldocchi, D and S Wong (2008). Accumulated winter chill is decreasing in the fruit growing regions of California. Climatic Change, 87, S153-S166.

Buchner, RP, JH Connell, FJ Niederholzer, CJ Debuse, KM Klonsky and RL De Moura (2012). Sample costs to establish a prune orchard and produce prunes (dried plums). Sacramento Valley. French Variety \& Low-Volume Irrigation.

Canadell, JG and MR Raupach (2008). Managing forests for climate change mitigation. Science, 320, 1456-1457.

Canadell, JG and ED Schulze (2014). Global potential of biospheric carbon management for climate mitigation. Nature Communications, 5.

CARB (2013). California Air Resources Board. Compliance offset protocol - US forest projects, Sacramento, CA.

Cardenas, JC, J Stranlund and C Willis (2000). Local environmental control and institutional crowding-out. World Development, 28, 1719-1733.

De Snoo, GR, I Herzon, H Staats, RJ Burton, S Schindler, J Van Dijk, AM Lokhorst, JM Bullock, M Lobley and T Wrbka (2013). Toward effective nature conservation on farmland: Making farmers matter. Conservation Letters, 6, 66-72. 
Difenbaugh, NS, TW Hertel, M Scherer and M Verma (2012). Response of corn markets to climate volatility under alternative energy futures. Nature Climate Change, 2, 14-518.

Diffenbaugh, NS, DL Swain and D Touma (2015). Anthropogenic warming has increased drought risk in California. Proceedings of the National Academy of Sciences of the United States of America, 112, 3931-3936.

Duncan, RA, PS Verdegaal, BA Holtz, DA Doll, KM Klonsky and RL De Moura (2011). Sample costs to establish an orchard and produce almonds. San Joaquin Valley North. Flood irrigation.

Gilroy, JJ, P Woodcock, FA Edwards, C Wheeler, BL Baptiste, CAM Uribe, T Haugaasen and DP Edwards (2014). Cheap carbon and biodiversity co-benefits from forest regeneration in a hotspot of endemism. Nature Climate Change, 4, 503-507.

Golet, GH, DL Brown, M Carlson, T Gardali, A Henderson, KD Holl, CA Howell, M Holyoak, JW Hunt and GM Kondolf (2013). Successes, failures and suggested future directions for ecosystem restoration of the middle Sacramento River, California. San Francisco Estuary and Watershed Science, 11, 1-29.

Grant, JA, JL Caprile, DA Doll, KK Anderson, KM Klonsky and RL De Moura (2013). Sample costs to establish a walnut orchard and produce walnuts. San Joaquin Valley. North Late leafing - lateral bearing.

Hayhoe, K, D Cayan, CB Field, PC Frumhoff, EP Maurer, NL Miller, SC Moser, SH Schneider, KN Cahill, EE Cleland, L Dale, R Drapek, RM Hanemann, LS Kalkstein, J Lenihan, CK Lunch, RP Neilson, SC Sheridan and JH Verville (2004). Emissions pathways, climate change, and impacts on California. Proceedings of the National Academy of Sciences of the United States of America, 101, 12422-12427.

Isik, M and W Yang (2004). An analysis of the effects of uncertainty and irreversibility on farmer participation in the conservation reserve program. Journal of Agricultural and Resource Economics, 29, 242-259.

Kamenica, E (2012). Behavioral economics and psychology of incentives. Annual Review of Economics, 4, 427-452.

Kittredge, DB, MG Rickenbach, TG Knoot, E Snellings and A Erazo (2013). It's the network: How personal connections shape decisions about private forest use. Northern Journal of Applied Forestry, 30, 67-74.

Knoot, TG and M Rickenbach (2011). Best management practices and timber harvesting: The role of social networks in shaping landowner decisions. Scandinavian Journal of Forest Research, 26, 171-182.

Krueger, WH, RP Buchner, JK Hasey, JH Connell, CJ Debuse, KM Klonsky and RL De Moura (2012). Sample costs to establish a walnut orchard and produce walnuts. English Walnuts. Sacramento Valley. Micro-Sprinkler Irrigated.

Kueper, AM, ES Sagor and DR Becker (2013). Learning from landowners: Examining the role of peer exchange in private landowner outreach through landowner networks. Society \& Natural Resources, 26, 912-930.

Lassner, J (1998). Valuing agricultural conservation easements. The Appraisal Journal, 66, $145-150$.

Lile, DF, DB Marcum, DL Lancaster, KM Klonsky and P Livingston (2013). Sample costs to establish and produce pasture. Irrigated in the intermountain region (Shasta, Lassen, and Modoc Counties).

Lubowski, RN, AJ Plantinga and RN Stavins (2006). Land-use change and carbon sinks: Econometric estimation of the carbon sequestration supply function. Journal of Environmental Economics and Management, 51, 135-152. 
Marvinney, E, A Kendall and S Brodt (2014). A comparative assessmet of greenhouse gas emissions in California almond, pistachio, and walnut production. In Proceedings of the 9th International Conference on Life Cycle Assessment in the Agri-Food Sector, San Francisco, CA, R Schenck and D Huizenga, (eds.), pp. 761-771.

Matzek, V, C Puleston and J Gunn (2015). Can carbon credits fund riparian forest restoration? Restoration Ecology, 23, 7-14.

McCarl, BA, X Villavicencio and X Wu (2008). Climate change and future analysis: Is stationarity dying? American Journal of Agricultural Economics, 90, 1241-1247.

NASS (2015). Quick Stats 2.0. National Agricultural Statistics Service. US Department of Agriculture.

Nelson, R, C Hellwinckel, C Brandt, T West, D De La Torre Ugarte and G Marland (2009). Energy use and carbon dioxide emissions from cropland production in the United States, 1990-2004. Journal of Environmental Quality, 38, 418-425.

Nielsen, ASE, AJ Plantinga and RJ Alig (2014). New cost estimates for carbon sequestration through afforestation in the United States. United States Forest Service.

Parks, PJ and IW Hardie (1995). Least-cost forest carbon reserves: Cost-effective subsidies to convert marginal agricultural land to forests. Land Economics, 71, 122-136.

Quartuch, MR and TM Beckley (2014). Carrots and sticks: New Brunswick and Maine forest landowner perceptions toward incentives and regulations. Environmental Management, 53, 202-218.

Reimer, AP, AW Thompson and LS Prokopy (2012). The multi-dimensional nature of environmental attitudes among farmers in Indiana: Implications for conservation adoption. Agriculture and Human Values, 29, 29-40.

Rodriguez, SL, MN Peterson, FW Cubbage, EO Sills and HD Bondell (2012). Private landowner interest in market-based incentive programs for endangered species habitat conservation. Wildlife Society Bulletin, 36, 469-476.

Saah, D, T Robards, T Buchholz and J Gunn (2012). Forest Carbon Forecaster: A carbon proforma tool to evaluate carbon market opportunities on private and public forestlands. S. I. G. M. C. F. C. Sciences. Available at http://www.manomet.org/sites/default/files/publications and_tools/SIG_MANOMET_Carbon_Proforma_V3_July_2012.xlsx.

Smith, JE, LS Heath, KR Skog and RA Birdsey. 2006. Methods for calculating forest ecosystem and harvested carbon with standard estimates for forest types of the United States. General Technical Report NE-343. U.S. Department of Agriculture, Forest Service, Northeastern Research Station. Newtown Square, PA.

Sorice, MG, W Haider, JR Conner and RB Ditton (2011). Incentive structure of and private landowner participation in an endangered species conservation program. Conservation Biology, 25, 587-596.

Strengers, BJ, JG Van Minnen and B Eickhout (2008). The role of carbon plantations in mitigating climate change: Potentials and costs. Climatic Change, 88, 343-366.

Sumner, DA and H Boriss (2006). Bee-conomics and the leap in pollination fees. Agriculture and Resource Economics Update, 9, 9-11.

Swain, DL, M Tsiang, M Haugen, D Singh, A Charland, B Rajaratnam and NS Diffenbaugh (2014). The extraordinary California drought of 2013-2014: Character, context, and the role of climate change. Bulletin of the American Meteorological Society, 95, S3-S7.

USDA (2013). Fertilizer Use and Price. Table 7 - Average U.S. farm prices of selected fertilizers, 1960-2013. USDA ERS. 
USDA (2015). Commodity Costs and Returns. Recent Costs and Returns: Corn. U.S.: 19962000, 2001-04, 2005-09, 2010-14, USDA.

Wright, SD, R Hutmacher, KM Klonsky and RL De Moura (2013). Sample costs to produce wheat for grain. San Joaquin Valley - South. Irrigated. 